Buoyant Capital Spending and Worries over Real Appreciation: Cold Facts from Algeria

Boileau Loko, Kangni Kpodar, and

Oumar Diallo 



\author{
IMF Working Paper \\ Middle East and Central Asia Department
}

\title{
Buoyant Capital Spending and Worries over Real Appreciation: Cold Facts from Algeria
}

\author{
Prepared by Boileau Loko, Kangni Kpodar, and Oumar Diallo ${ }^{1}$ \\ Authorized for distribution by \\ Domenico Fanizza
}

December 2007

\begin{abstract}

\section{This Working Paper should not be reported as representing the views of the IMF.}

The views expressed in this Working Paper are those of the author(s) and do not necessarily represent those of the IMF or IMF policy. Working Papers describe research in progress by the author(s) and are published to elicit comments and to further debate.
\end{abstract}

The Government of Algeria has pursed a relatively expansionary fiscal policy in recent years, thanks to rising oil prices and revenues. The paper explores the potential effects of such a stance on real exchange rate and uncovers a relatively small appreciating effect of increased government capital expenditure. This is explained by the fact that a significant share of capital spending falls into tradable imported goods. However, the envisaged increase in capital spending, if well designed and implemented, might in the long-run translate into rising operations and maintenance expenditure - mostly nontradable goods - thereby causing a higher real appreciation. This implies that Algeria should carefully consider the implications of its public investment program on recurrent expenditure.

JEL Classification Numbers: E62, F41, Q33

Keywords: Government capital expenditure, real exchange rate, oil

Authors’ E-Mail Addresses: bloko@,imf.org, kkpodar@imf.org, dialloo@un.org

\footnotetext{
${ }^{1}$ Oumar Diallo is an economist in the Development Policy and Analysis Division/Department of Economic and Social Affairs (DPAD/DESA) of the United Nations Secretariat. The views and opinions expressed in the paper are those of the author and do not necessarily reflect those of the United Nations Secretariat. We would like to thank Laurence Allain, Domenico Fanizza, Gabriel Sensenbrenner, Leonce Ndikumana, Tashin Saadi-Sedik, Jacques Bougha Hagbe, and Juan Zalduendo for useful comments and suggestions.
} 


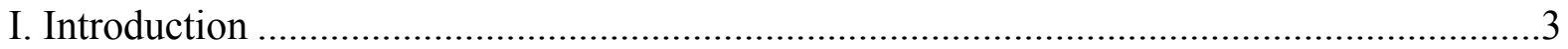

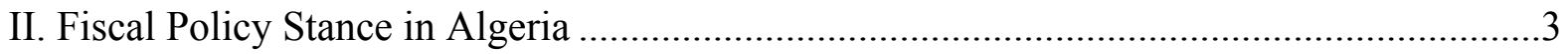

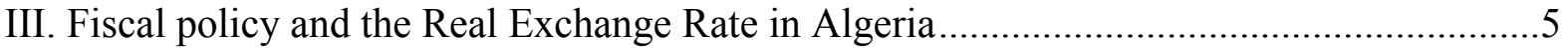

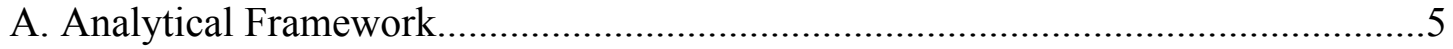

B. Empirical Model Specification..................................................................

C. Data, Estimation, and Results ................................................................... 10

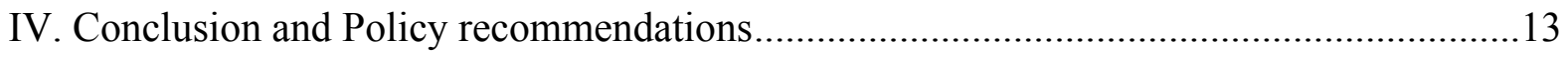

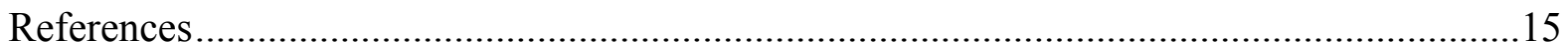

Tables

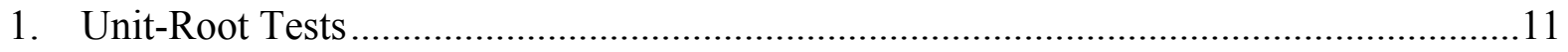

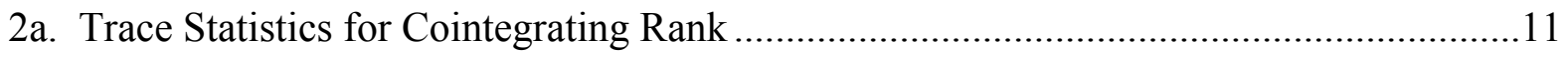

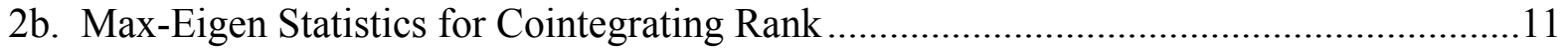

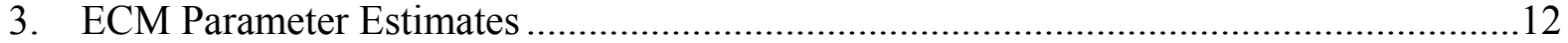

Figures:

1. Public Expenditure and Oil Prices, 1970-2005 ...........................................................

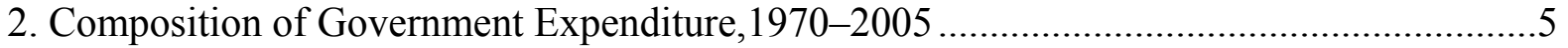

3. Imports and Government Expenditures, 1995-2005 .................................................13

Appendixes:

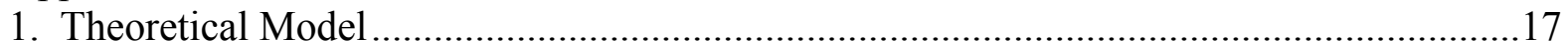

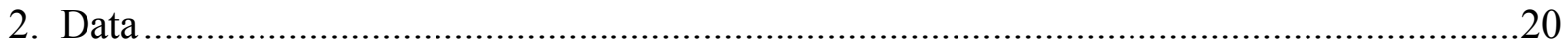

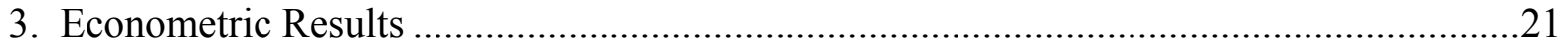




\section{INTRODUCTION}

A favorable external environment and appropriate macroeconomic policies have contributed to Algeria's encouraging economic performance over the past five years. Economic growth has relatively been brisk, inflation has remained low, and current account position has strengthened markedly. Also, the authorities decided to use part of the fiscal space created by hydrocarbon revenues to increase public spending. The government of Algeria has launched an ambitious five-year public investment program, the Growth Consolidation Plan (GCP), which aimed at improving infrastructure, housing and the delivery of public services.

The recent surge in public spending, in particular in capital expenditure, carries some risks. In particular, increased domestic use of hydrocarbon revenues may lead to an appreciation of the real exchange rate, which has the potential to undermine the competitiveness of the nonhydrocarbon tradable sector and to hamper the efforts of the Algerian government to expand economic activity beyond the hydrocarbon sector. ${ }^{2}$ Therefore, understanding the impact of government spending on the economy, and particularly on the real effective exchange rate, is potentially of great importance to economic policy-makers.

The empirical work carried out in this paper suggests that, in the case of Algeria, the increase in government capital spending has had so far a limited appreciating impact on the real exchange rate. We argue that government spending generates foreign exchange outflows, insofar as public spending has high import content, attenuating somewhat the appreciating effect of the spending. However, along with ensuring fiscal sustainability and the quality of capital spending, the authorities should carefully consider the implications of the public investment program on future recurrent expenditure, as these goods are mostly nontradables.

The remaining of the paper is organised as follows. Section II provides a brief overview of fiscal policy in Algeria. Section III highlights the theoretical arguments underlying the nexus between fiscal policy and real exchange rate, and then confronts these arguments with empirical evidence, relying on a revised version of the theoretical model developed by Cashin and al. (2004). Finally, the last section concludes and draws some policy implications from our analysis.

\section{Fiscal Policy Stance in Algeria}

The hydrocarbon sector dominates the Algerian economy, accounting for almost 45 percent of GDP in 2005 and 98 percent of exports of goods. The state-owned petroleum company (Sonatrach) fully repatriates and surrenders foreign currency receipts generated by hydrocarbon exports to the bank of Algeria. ${ }^{3}$ Such earnings are generally divided between the government, and Sonatrach and its subsidiaries. On average, two-third of export receipts

\footnotetext{
${ }^{2}$ This phenomenon is commonly referred to as Dutch disease (Corden, 1984).

${ }^{3}$ Sonatrach's activities include petroleum exploration, oil and gas production and marketing, and pipeline transportation. Algeria's exchange rate regime is a managed float with no pre-announced path of the exchange rate.
} 
accrue to the treasury, making government revenue highly dependent on oil prices ${ }^{4}$ fluctuations, thus volatile. Similarly, public spending appears erratic, following very much the same features as those displayed by government revenue and oil prices.

Figure 1. Public Expenditure and Oil Pirces, 1970-2005

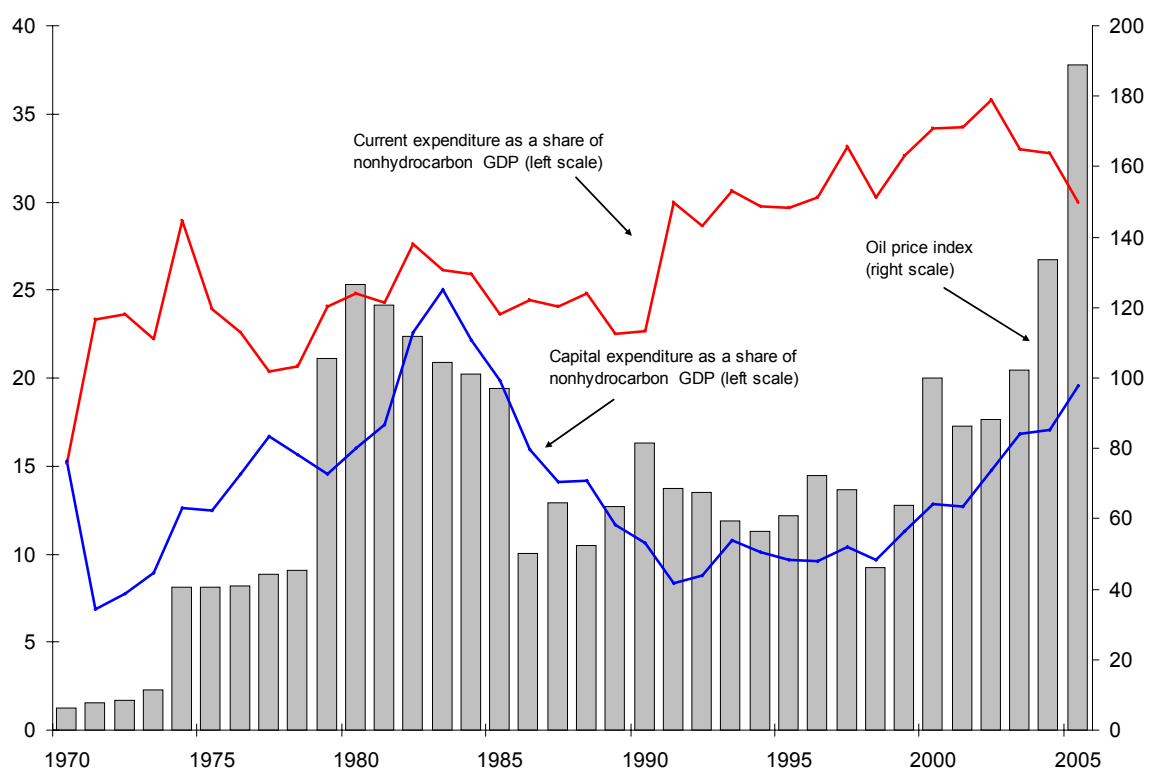

Sources: Algeria authorities; and Fund staff estimates.

Indeed, high hydrocarbon prices allowed the government of Algeria to increase public spending in the 1970s and in the beginning of the 1980s. Capital expenditure accounted for much of these increases. The dynamics changed when hydrocarbon prices collapsed during the second half of the 1980s. Public investment was cut significantly, but current expenditure remained high (Figure 1). The outcomes of maintaining relatively high levels of current spending were rising fiscal deficits, depleting official reserves, extensive external and internal borrowing, rising inflation, and intensifying import restrictions. The country then embarked on a Fund-supported program in 1994 that was accompanied by a fiscal tightening during 1994-98.

Thereafter, the Algerian government has pursued a somewhat expansionary fiscal policy thanks to rising hydrocarbon prices. The government implemented the economic recovery Program (ERP) between 2001 and 2004. Capital expenditure increased from about 8 percent of GDP in 2001 to 11 percent of GDP in 2004. In 2005, the authorities launched the Growth Consolidation Program 5 (2005-09) with the objective of improving infrastructure and

\footnotetext{
${ }^{4}$ Because of the high positive correlation between gas and oil prices, we use oil prices as a proxy for hydrocarbon prices.

${ }^{5}$ In total, the public investment program for 2005-09 amounts to about $\$ 140$ billion (about 140 percent of 2005 GDP).
} 
generating employment. As the program was in the early stages of implementation, the execution rates of capital spending were low during 2005. Therefore, capital spending remained stable at about 11 percent of GDP in 2005, although the composition of public spending has shifted towards capital spending (Figure 2).

Figure 2. Composition of Government Expenditure, 1970-2005

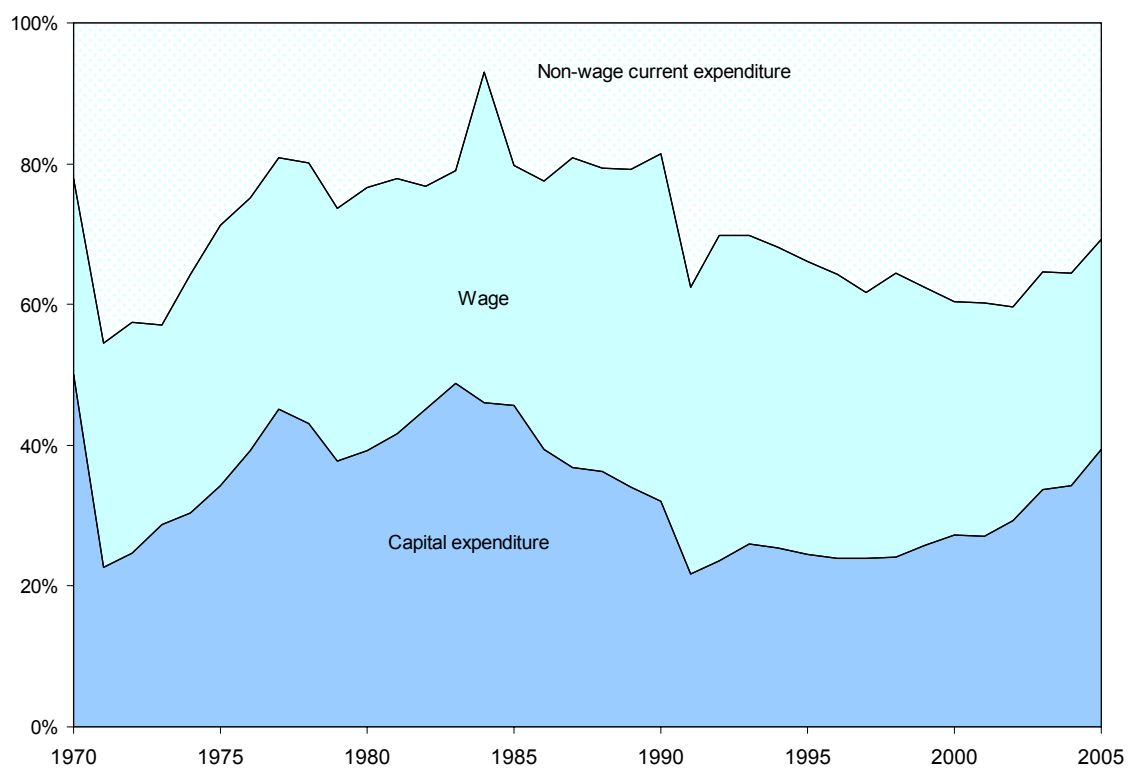

Sources: Algerian authorities; and Fund staff estimates.

In a country that is still recovering from a period of political instability and civil strive, as it is the case in Algeria, policy makers have to weigh the medium and long-term benefits of a prudent fiscal stance against the immediate needs of a fragile economy and social demands. However, significant and rapid increases carries some risks. First with planning, implementation and management capacity being limited, there is a risk that additional fiscal resources are channelled to inefficient and unstainable capital projects and current expenditure programs. Second, the current fiscal policy stance might generate inflationnary pressures and eventually lead to real exchange rate appreciation. That may contribute to deteriorating the competiveness of the nonhydrocarbon traded goods sector.

\section{Fiscal policy AND the Real Exchange Rate in Algeria}

\section{A. Analytical Framework}

The theoretical framework builds on Cashin and others' (2004) model which links the real exchange rate to real commodity prices. We extend the model by incorporating government 
spending so as to capture its effect on the real exchange rate. ${ }^{6}$

There are three goods (nontradable, exportable - primary commodity — and final tradable), two economic agents ${ }^{7}$ (household/firms and government). The country is a small open economy that produces a nontradable good and an exportable good that is assumed to be a primary commodity (not consumed domestically). Both goods are produced by firms using constant-returns- to scale technology.

Labor is the only factor of production and it is freely mobile between sectors, thereby ensuring that wages are equated across sectors and that only supply-side factors are relevant. We assume that labor supply is inelastic. Domestic households consume both a nontraded and a final tradable good, imported from abroad and not produced domestically. Foreign firms use the primary commodity joint with an intermediate good, produced only abroad, as inputs in the production process of the final tradable good. Foreign households consume both nontraded and final tradable goods.

We assume that the government (either domestic or foreign) consumes both a nontradable and a final tradable good just like the representative household does, but the parameters of its utility function are different. Specifically, it is assumed that the government's preference for the nontraded good (or the traded good) differs from the households' ${ }^{8}$.

The real exchange rate is defined as the foreign price of the domestic basket of consumption $(E P)$ relative to the foreign price of the foreign basket of consumption $\left(P^{*}\right)$. The real effective exchange rate (REER) is given by the following equation (see Appendix 1 for more details):

$\frac{E P}{P^{*}}=\left(\frac{a_{x}}{a_{1}^{*}} \frac{a_{N}^{*}}{a_{N}} \frac{P_{X}^{*}}{P_{1}^{*}}\right)^{\gamma(1-P u)+g P u}$

where $\frac{P_{X}^{*}}{P_{1}^{*}}$ represents the commodity terms of trade measured in foreign prices, $\frac{a_{x}}{a_{1}^{*}}$ denotes the productivity differentials between the export and the import sectors, $\frac{a_{N}^{*}}{a_{N}}$ captures the productivity differentials between the local and foreign nontraded sectors, $\gamma$ is the elasticity of household consumption or spending to the nontraded good, $g$ captures the elasticity of

\footnotetext{
${ }^{6}$ Our theoretical model falls into the category of the behavioral equilibrium exchange rate (BEER) models.

${ }^{7}$ Cashin and others consider only one representative agent: the household.

${ }^{8}$ We assume that there is no distinction between consumption and investment. The final good can be either consumed or invested
} 
government consumption or spending to the nontraded good, and $P_{u}$ is the government's share in total aggregate demand.

The terms $\frac{a_{x}}{a_{1}^{*}}$ and $\frac{a_{N}^{*}}{a_{N}}$ embody the Balassa-Samuelson effect, whereby higher productivity in the commodity sector will tend to increase wages and the price of the nontraded good, and ultimately result in an appreciation of the real exchange rate. The parameter $g$ (respectively $\gamma$ ) reflects the government (respectively households) relative preference for the nontraded good. A value of $g$ higher than $\gamma$ would imply that government spending is relatively more biased toward the nontraded good compared with household spending. Conversely a value of $g$ lower than $\gamma$ would imply that government spending is relatively biased toward the traded good. ${ }^{9}$

Taking the log of equation (1) yields:

$$
\log (R E E R)=(\gamma(1-P u)+g P u) \log \left(\frac{a_{x}}{a_{1}^{*}} \frac{a_{N}^{*}}{a_{N}} \frac{P_{X}^{*}}{P_{1}^{*}}\right)
$$

The marginal effect of a change in real price of the primary commodity is given by:

$$
\frac{\partial \log (R E E R)}{\partial \log \left(\frac{P_{X}^{*}}{P_{1}^{*}}\right)}=\gamma(1-P u)+g P u
$$

Equation (3) suggests that a rise in the relative price of the primary commodity will result in an appreciation of the real exchange rate. The increase in commodity price boosts wages in the primary commodity sectors, and as wages are assumed to equalize across sectors owing to labor mobility, both the wages and the price of the nontraded sector will increase as well.

The marginal impact of a change in government spending on the real exchange rate is as follows:

$$
\frac{\partial \log (R E E R)}{\partial P u}=\alpha \log \left(\frac{a_{x}}{a_{1}^{*}} \frac{a_{N}^{*}}{a_{N}} \frac{P_{X}^{*}}{P_{1}^{*}}\right)
$$

\footnotetext{
${ }^{9}$ Our model is equivalent to that of Cashin and others (2004) when $P_{u}=0$ (no government spending) or $g=\gamma$ (government and households share the same preferences). In that case, equation (1) will give: $\frac{E P}{P^{*}}=\left(\frac{a_{x}}{a_{1}^{*}} \frac{a_{N}^{*}}{a_{N}} \frac{P_{X}^{*}}{P_{1}^{*}}\right)^{\gamma}$.
} 
With $\alpha=g-\gamma$

Since much of the current public spending and a non-negligible share of capital spending fall on nontradables in Algeria, we assume that the share of non-traded goods in government spending is much higher than that the share of non-traded goods in private spending $(\alpha \succ 0)$, just as in many other developing countries.

Equation (4) indicates that increasing government spending has an appreciating effect, although the magnitude of such an appreciating effect depends on relative share of on nontraded goods in government spending. The higher is this share, the more pronounced is the appreciation of the real exchange rate. In addition, an increase in the relative share of the nontraded good in public spending with an unchanged level of public spending leads unambiguously to an appreciation of the reel exchange rate as suggested by equation (5).

$$
\frac{\partial \log (R E E R)}{\partial g}=P u \log \left(\frac{a_{x}}{a_{1}^{*}} \frac{a_{N}^{*}}{a_{N}} \frac{P_{X}^{*}}{P_{1}^{*}}\right)
$$

These findings are similar to those of Sachs and Wyplosz (1984), who developed a model where the effect of fiscal policy changes on the real exchange rate lies on the composition of government spending relative to that of the private sector. If the public marginal propensity to import is lower than that of the private sector, the fiscal expansion alters the composition of spending by shifting demand away from foreign goods toward domestic goods, thus leading to a real exchange rate appreciation.

\section{B. Empirical Model Specification}

Based on the above analytical framework, we assume that, in a commodity dependant economy such as Algeria, three factors are likely to be important in explaining the real effective exchange rate:

The real price of the primary commodity (the world price of oil): Given that hydrocarbons account for a substantial fraction of Algeria's exports earnings, we use world price of oil in real terms, as a proxy for external terms of trade. Higher oil prices lead to higher wages which in turn would result in higher prices for nontradables and thus in real appreciation.

Differential productivity: Productivity convergence, according to the Balassa-Samuelson effect, would be associated with a real exchange rate appreciation. We expect increased relative productivity in the economy, particularly in the tradable sector, to lead to a real appreciation.

Government expenditure: We expect higher oil prices to lead to higher government spending, which in turn would appreciate the real exchange rate. However, the magnitude of the appreciation lies on a number of factors including the share of tradables and nontradables in government spending.

The empirical model for the real exchange rate (REER) can be represented by: 
$\operatorname{REER}_{t}=f\left(\right.$ PROD $_{t}$, Oil $\left._{t}, G K_{t}\right)$

where REER represents the real effective exchange rate, PROD, the differential productivity between the home country and abroad, Oil, the real oil price, and GK is government capital spending as a share of GDP.

Following the Johansen $(1988,1995)$ maximum likelihood methodology, the complete empirical model specification can be represented as a vector autoregressive (VAR), with the following form:

$X_{t}=\phi^{0}+\sum_{j=1}^{q} \phi_{j} X_{t-1}+\omega_{t}$

where $_{X_{t}}=\left[\begin{array}{l}R E E R_{t} \\ P R O D_{t} \\ O i l_{t} \\ G K_{t}\end{array}\right]$ while $\omega_{\mathrm{t}}, \mathrm{a}(4 * 1)$ vector, captures the errors terms, $\phi_{j}$ denotes a (4*4) matrix of coefficients on lags of $X_{t} ; \phi^{0}$ represents a $(4 * 1)$ vector of deterministic variables, and $q$ is the number of lags. Further, we assume $\omega_{\mathrm{t}}$ to be a vector of independent and identically distributed errors (iid) that follows a normal distribution, with zero mean and covariance matrix $\Omega$.

We transform relation (6) into a vector error correction model (VECM) by adding and taking away lags of $X_{t}$ and obtain the following:

$\Delta X_{t}=\phi^{0}+\phi X_{t-1}+\sum_{j=1}^{q-1} \Delta \Pi_{j} X_{t-j}+v_{t}$

where $\phi \equiv\left(\sum_{j=1}^{q} \phi_{i}\right)-I$ and $\Pi_{j}=-\left(\phi_{j+1}+\ldots+\phi_{q}\right)$.

The number of cointegration relations is equal to the rank of $\phi$. Thus, a rank of $\phi$, equal to $v,{ }^{10}$ means that there are $v$ cointegrating vectors; $\phi$ can then be represented as a combination of two full-column rank ( $4 *^{*}$ ) matrices: $\varphi$ and $\chi\left(\phi=\varphi \chi^{\prime}\right)$. Substituting such a relation in (8) leads to:

$\Delta X_{t}=\phi^{0}+\varphi \chi^{\prime} X_{t-1}+\sum_{j=1}^{q-1} \Delta \Pi_{j} X_{t-j}+v_{t}$

${ }^{10} 0<v<4$. 
It is worth noting that the matrix $\chi^{\prime}$ contains the cointegrating vectors while $\varphi$ columns capture the feedback effects.

\section{Data, Estimation, and Results}

The estimation uses annual data series covering the period 1970-2006, and the variables of interest are those highlighted in the above model specification. The data are drawn mostly from the World Economic Outlook (WEO) database (See Appendix 2). In order to estimate the empirical model, we first test for the presence of unit roots in the series using the Augmented Dickey Fuller (ADF) and the Phillips-Perron (PP) tests. Both tests do not reject the null hypothesis of a unit root. All series are integrated of order one (Table 1).

In the second step, we check for the existence of cointegration among the real effective exchange rate, the differential productivity, the real oil price and government spending using the Johansen cointegration test. However, many authors (for instance Gonzalo, 1994) indicate that the Johansen approach may be sensitive to the choice of the lag length. In this context, we use the AIC procedure to choose the number of lags (4).

Another important shortcoming with the Johansen approach is the bias associated with the use of small samples (Johansen, 2002). Many studies reveal that in small samples, the Johansen approach fails to reject the null hypothesis of noncointegration even if there is no cointegration vector. One way of addressing the bias is to correct the test statistic so that the finite sample distribution is closer to the asymptotic distribution (Reinsel and Ahn, 1988, Johansen, 2002). ${ }^{11}$

To correct for a possible small sample bias, we use Reinsel and Ahn's approach which suggests that the critical value be adjusted upward by a multiplicative scaling factor, $T /(T-n j)$, with $T$ the sample size, $n$ the number of variables, and $j$ the number of lags. After correcting the critical values, both Trace and Max-Eigen statistics reject the null hypothesis of zero cointegrating equation. Both tests indicate the presence of one cointegrating vector (Table 2).

The cointegration relationship, normalized on the real effective exchange rate (Table 3 ), suggests that:

- $\quad$ The REER appreciates as oil prices increase. For example, a one percent increase in real oil prices will appreciate the real effective exchange rate by 0.3 percent.

- $\quad$ The parameter associated with the differential productivity suggests, as expected, that an improvement in domestic productivity leads to an appreciation of the real exchange rate. A one percent worsening in Algeria' productivity differential has more than one-to-one depreciating effect on the exchange rate. In the case of Algeria, the steady worsening of productivity in Algeria would lead to a real depreciation.

\footnotetext{
${ }^{11}$ Another way of addressing the small sample bias is the bootstrap procedure to estimate the p-value of the test statistic. Using the BDS test and the bootstrap procedure, we check whether the estimated residuals are independent and identically distributed (iid). The results show that the residuals are iid.
} 
Table 1. Unit-Root Tests

\begin{tabular}{lrrrr}
\hline & ADF & ADF (with trend) & PP & PP (with trend) \\
\hline Level & & & & \\
LREER & -0.175 & -2.325 & -0.369 & -1.765 \\
LOIL & -2.272 & -2.248 & -2.274 & -2.248 \\
LPROD & -0.262 & -2.158 & -0.179 & -2.080 \\
LGK & -2.333 & -2.712 & -2.263 & -2.154 \\
& & & & \\
First Difference & & & $-4.424^{*}$ & $-4.464^{*}$ \\
LREER & $-4.439^{*}$ & $-4.428^{*}$ & $-6.106^{* * *}$ & $-6.030^{* * *}$ \\
LOIL & $-6.106^{* * *}$ & $-6.030^{* * *}$ & $-7.854^{* * *}$ \\
LPROD & $-8.428^{* * *}$ & $-8.608^{* * *}$ & $-7.750^{* * *}$ & $-6.666^{* * *}$ \\
LGK & $-7.220^{* * *}$ & $-7.061^{* * *}$ & $-6.828^{* * *}$ & \\
& & & & \\
\hline
\end{tabular}

Notes: LREER, LOIL, LPROD, LGK stand for the log of the real effective exchange rate, the log of the real price of oil, the log of the productivity differential, and the log of the ratio capital expenditure to GDP, respectively. The lag length is determined based on Schwarz information criterion (SIC). *Significant at 1 percent; ** Significant at 0.1 percent; ** Significant at 0.01 percent.

Table 2a.Trace Statistics for Cointegrating Rank

\begin{tabular}{rrrrr}
\hline & Eingevalue & $\begin{array}{r}\text { Trace } \\
\text { Statistics }\end{array}$ & Critical Value & $\begin{array}{r}\text { Critical value } \\
\text { adjusted }\end{array}$ \\
\hline $\mathrm{r}=0$ & 0.92 & $136.7^{*}$ & 47.9 & 98.9 \\
$\mathrm{r} \leq 1$ & 0.69 & 57.9 & 29.8 & 61.6 \\
$\mathrm{r} \leq 2$ & 0.48 & 21.7 & 15.5 & 32.0 \\
$\mathrm{r} \leq 3$ & 0.04 & 1.3 & 3.8 & 7.9 \\
\hline
\end{tabular}

*Significant at 5 percent; $r=$ cointegrating rank

Table 2b. Max-Eigen Statistics for Cointegrating Rank

\begin{tabular}{rrrrr}
\hline & Eingevalue & $\begin{array}{r}\text { Max-Eigen } \\
\text { statistics }\end{array}$ & Critical Value & $\begin{array}{r}\text { Critical value } \\
\text { adjusted }\end{array}$ \\
\hline $\mathrm{r}=0$ & 0.92 & $78.9 .2^{*}$ & 27.6 & 57.0 \\
$\mathrm{r} \leq 1$ & 0.69 & 36.2 & 21.1 & 43.7 \\
$\mathrm{r} \leq 2$ & 0.48 & 20.4 & 14.3 & 29.5 \\
$\mathrm{r} \leq 3$ & 0.04 & 1.3 & 3.8 & 7.9 \\
\hline
\end{tabular}

*Significant at 5 percent; $r=$ cointegrating rank 
- An increase in government capital expenditure is associated with an appreciation of the exchange rate. However, the impact appears relatively small: for example, a 10 percent increase in capital spending to GDP ratio will appreciate the real effective exchange rate by 0.3 percent, suggesting that a non negligible proportion of government spending is directed toward tradable goods.

Table 3. ECM Parameter Estimates

\begin{tabular}{lr}
\hline Dependent variable: & \multicolumn{2}{l}{ LREER } \\
\hline Adjustment Speed & $-0.78^{* *}$ \\
& $(0.2)$ \\
Long-Run Parameters & $0.26^{* * *}$ \\
LOIL & $(0.05)$ \\
& $1.36^{* * *}$ \\
LPROD & $(0.04)$ \\
& $0.13^{* *}$ \\
LGK & $(0.07)$ \\
& 0.82 \\
Adjusted $\mathrm{R}^{2}$ & \\
\hline $\begin{array}{l}\text { Notes: } * * * \text { denotes significance of the estimates at } 1 \text { percent } \\
\text { critical level; ** at } 5 \text { percent critical level; * at } 10 \text { percent critical } \\
\text { level. }\end{array}$
\end{tabular}

The relatively small impact of government capital on the real exchange rate is broadly consistent with the results of a further analysis of the public spending structure in Algeria. First, capital expenditure, which represents one-third of total expenditure, usually includes a significant fraction of equipment and goods that are not domestically produced. Thus, an increase in capital spending boosts the demand for imported consumer goods and equipment. The causality from capital spending to imports is confirmed by the Granger test (See Appendix 3). ${ }^{1}$ This strong correlation between public expenditure and imports is also shown by the co-movements between these variables, especially during the recent years (Figure 3).

\footnotetext{
${ }^{1}$ The results of the Granger Causality test should be interpreted with caution as the findings are only suggestive rather than conclusive about the causality between two variables. Granger causality captures precedence and information content and does not always have the general meaning of the term.
} 
One might also expect rising public investment, if well targeted, to ease supply constraints in both the tradable and the non-tradable sectors ${ }^{2}$ in the long-run, thereby attenuating the appreciation of the real exchage rate.

Figure 3. Imports and Government Expenditures, 1995-2005

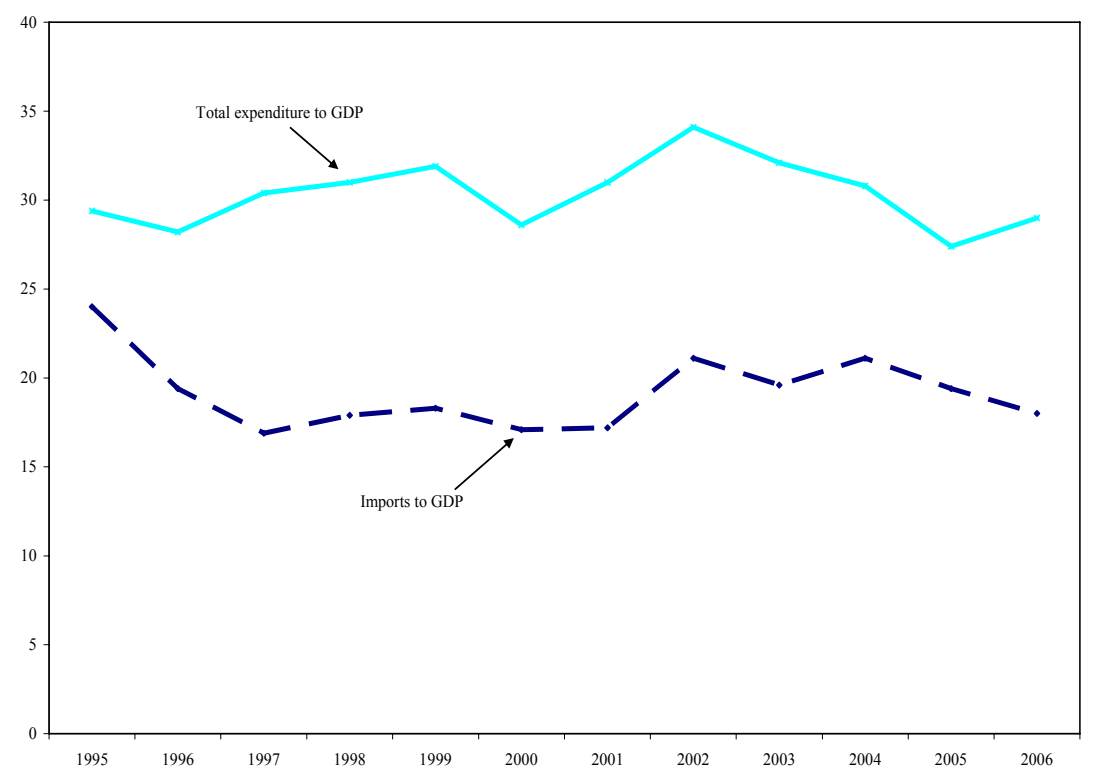

Sources: Algerian authorities and Fund staff estimates.

\section{Conclusion ANd Policy Recommendations}

The decayed and overstretched economic infrastructure along with the inadequate institutional and regulatory framework for private sector development certainly hampers the emergence of a vibrant non-hydrocarbon sector. Thus, fixing and extending the economic infrastructure is required if Algeria is to promote an alternative growth engine to the hydrocarbons sector, and the current ambitious investment program constitutes an important step towards the right direction.

This paper finds that an increase in government capital expenditure is associated with a relatively small appreciation of the exchange rate, suggesting that an important proportion of capital spending is so far directed toward imported goods. That might change. In particular, the envisaged increase in capital spending, if well designed and implemented, might in the long-run translate into rising operations and maintenance expenditure - mostly nontradable goods - thereby causing a higher real appreciation, with potential adverse implications for the nonhydrocarbon sector.

Therefore, along with ensuring fiscal sustainability and the quality of capital spending, the authorities should carefully consider the implications of the public investment program on recurrent expenditure. Structural policies encouraging private sector saving, investing part of

\footnotetext{
${ }^{2}$ Increasing imports of consumer goods and equipment could improve the productivity of the nontradable goods and contribute to decrease the price of nontradables.
} 
the foreign exchange inflows in foreign assets, and a good coordination between fiscal and monetary policies can help avoid a strong real exchange rate appreciation.

Further, the potential pressure on real exchange rate could be dampened if current expenditure, especially recurrent spending, makes more use of production factors, goods, and services that are in excess supply in the economy. Nevertheless, getting the real exchange rate right and economic infrastructure fixed and expanded alone would not be enough to put the nonhydrocarbon on the path of robust and sustainable growth. It would also be crucial for Algeria to implement policies and productivity enhancing reforms that will secure high and sustained growth rates of the nonhydrocarbon sector. 


\section{REFERENCES}

Ahn, S.K. and G.C. Reinsel, 1988, "Nested reduced rank autoregressive models for multiple time series", Journal of the American Statistical Association, Vol.83, pp. 849-56.

Barro, R. J., 1974, “Are Government Bonds Net Wealth?,” Journal of Political Economy, Vol. 82, No 6, pp. 1095-117.

Cashin, P., F. Céspedes, and R. Sahay, 2004, "Commodity Currencies and the Real Exchange Rate”, Journal of Development Economics, Vol. 75, No 1, pp. 239-68.

Cerra, V. and S.C. Saxena, 2002, "What Caused the 1991 Currency Crisis in India?", IMF Staff Papers, International Monetary Fund, Vol. 49, pp. 395-425.

Clark, P., and R. MacDonald, 1998, "Exchange Rates and Economic Fundamentals: A Methodological Comparison of BEERs and FEERs", IMF Working Paper 98/67, (Washington: International Monetary Fund).

Corden, W., 1984, "Booming Sector and Dutch Disease Economics: Survey and Consolidation," Oxford Economic Papers, Vol. 36, pp. 359-80.

Evans, P., 1988, “Are Consumers Ricardian? Evidence for the United States," Journal of Political Economy, Vol. 96, No 5, pp. 983-1004.

Frenkel, J., and A. Razin, 1989, "Fiscal Policies and Real Exchange Rates in the World Economy" NBER Working Paper 2065, National Bureau of Economic Research, Inc.

Gonzalo, J., 1994, "Five alternative methods of estimating long-run equilibrium relationships", Journal of Econometrics, Vol.60, pp. 203-33.

Granger, C.W.J., 1969, "Investigating Causal Relations by Econometric Methods and CrossSpectral Methods" Econometrica, Vol. 34, pp. 424-38.

Hemming, R., M. Kell, and S. Mahfouz, 2002, "The Effectiveness of Fiscal Policy in Stimulating Economic Activity-A Review of the Literature," IMF Working Paper 02/208, International Monetary Fund.

Johansen, S., 1988, "Statistical Analysis of Cointegration Vectors", Journal of Economic Dynamics and Control, Vol.2 (June-September), pp. 231-54. 
Johansen, S., 1995, Likehood-based Inference in Cointegrated Vector Autoregressive Models (Oxford, United Kingdom: Oxford University Press).

Johansen, S., 2002, "A Small Sample Correction for Tests of Hypotheses on the Cointegrating Vectors", Journal of Econometrics, Vol.111 (December), pp. 195-221.

Koranchelian, T., 2005, "The Equilibrium Real Exchange Rate in a Commodity Exporting Country: Algeria's Experience," IMF Working Paper 05/135, International Monetary Fund.

Sachs, J., and C. Wyplosz, 1984, "Real Exchange Rate Effects of Fiscal Policy," NBER Working Paper 1255, National Bureau of Economic Research, Inc. 


\section{APPEndix 1. TheORetical Model}

This part presents the model used in this paper. Following Cashin and others (2004), we consider a small open economy that produces two types of goods: a nontraded good and an exportable good that is associated with the production of a primary commodity. We extend the model by incorporating government spending so as to capture its effect on the real exchange rate.

\section{Domestic production:}

Consider a small open economy producing two types of goods: a nontradable good and an exportable good that is considered a primary commodity. Assuming that perfect competition holds within both sectors and that labor is the only factor of production and is, in addition, freely mobile across sectors, the primary commodity production function is given by: $Y_{X}=a_{X} L_{X}$, where $L_{X}$ is the amount of labor needed to produce one unit of output in the export sector, and $a_{x}$ is the labor productivity in the export sector.

Similarly, the production function of the nontradable good is given by: $Y_{N}=a_{N} L_{N}$, where $L_{N}$ and $a_{N}$ represent the employment and the labor productivity in the nontradable sector, respectively. Profit maximization in both sectors yields the following conditions: $P_{X}=\frac{w}{a_{X}}$ and $P_{N}=\frac{w}{a_{N}}$, where $w$ denotes the labor wage, $P_{X}$ is the domestic price of the primary commodity and $P_{N}$ represents the domestic price of the nontraded good. Given that the real equilibrium wage is the same in both sectors, the price of the nontraded good can be expressed as a function of the price of the exportable and the ratio of the export sector productivity to that of the nontradable sector:

$P_{N}=\frac{a_{X}}{a_{N}} P_{X}$

Thus, the relative price of the nontraded good $\left(P_{N}\right)$ with respect to the primary commodity $\left(P_{X}\right)$ is solely determined by technological factors and is independent of demand conditions. Notice that an increase in the price of the primary commodity will boost wages in that sector. Because of labor mobility, such a wage rise would trigger wage and price increases in the nontraded good.

\section{Domestic aggregate demand}

Household labor supply $\left(L=L_{X}+L_{N}\right)$ is inelastic and their consumption consists of a nontraded and tradable goods. The tradable good is not produced domestically and is imported from the rest of the world, while the primary commodity is exported and not 
consumed domestically. Here, we assume that there is no distinction between consumption and investment. The final goods can be either consumed or invested in capital.

Each household chooses a combination nontraded and tradable goods that maximizes its utility. Household utility is assumed to be increasing in the level of aggregate private consumption given by : $C=\kappa C_{N}^{\gamma} C_{T}^{1-\gamma}$, where $C_{N}$ represents the purchase of the nontraded good, $C_{T}$ denotes the purchase of the tradable good, $\kappa$ is a constant and $\gamma$ captures the elasticity of private consumption with respect to the nontraded good. The minimum cost of one unit of private consumption is given by: $P_{C}=P_{N}^{\gamma} P_{T}^{1-\gamma}(o \leq \gamma \leq 1)$, where $P_{T}$ is the price in local currency of one unit of the tradable good.

Unlike Cashin and others (2004), government spending is introduced in the model. Although we assume that the government consumes both nontraded and tradable goods, government spending patterns differ from those of private agents ${ }^{3}$. With $g$ denoting the elasticity of public spending to the nontraded good, the minimum cost of one unit of public consumption is given by: $P_{G}=P_{N}^{g} P_{T}^{1-g}(o \leq g \leq 1)$. The aggregate domestic price level is given by:

$$
\begin{aligned}
P & =P_{C}^{1-P u} P_{G}^{P u} \\
& =\left(P_{N}^{\gamma} P_{T}^{1-\gamma}\right)^{1-P u}\left(P_{N}^{g} P_{T}^{1-g}\right)^{P u}
\end{aligned}
$$

where $P_{u}$ is the share of public spending in total aggregate demand.

The law of one price is supposed to hold for the imported good so that: $P_{T}=\frac{P_{T}^{*}}{E}$, where $E$ is the nominal exchange rate defined as the amount of foreign currency per local currency, and $P_{T}^{*}$ is the price of the tradable good in terms of foreign currency.

\section{Foreign production and aggregate demand}

The production structure of the foreign region ${ }^{4}$ comprises three different sectors: a nontraded sector, an intermediate sector, and a final good sector. Similar to the domestic economy, the foreign nontraded sector uses labor as the only production factor and a constant returns to scale technology represented by the following: $Y_{N}^{*}=a_{N}^{*} L_{N}^{*}$. The same technology is used to produce an intermediate good that enters into the production of the final good. The

\footnotetext{
${ }^{3}$ Since much of the current public spending and a non-negligible share of capital spending fall on nontradables in Algeria, we assume that the share of non-traded goods in government spending is much higher than that the share of non-traded goods in private spending, just as in many other developing countries.

${ }^{4}$ In the model, the foreign region does mean the rest of the world. The rest of the world also includes other countries producing the primary commodity.
} 
production function of the intermediate good is captured by: $Y_{1}^{*}=a_{1}^{*} L_{1}^{*}$. Labor is supplied inelastically by households and mobile across sectors but not across regions. The following condition holds when wage is equated across sectors:

$$
P_{N}^{*}=\frac{a_{1}^{*}}{a_{N}^{*}} P_{1}^{*}
$$

The final tradable good is produced using the foreign intermediate good $Y_{1}$ and the foreign primary commodity $Y_{X}$ (several countries including the domestic economy produce the primary commodity). The production function is as follows: $Y_{T}^{*}=v\left(Y_{1}^{*}\right)^{\beta}\left(Y_{X}^{*}\right)^{1-\beta}$. This implies that the cost of one unit of the tradable good in terms of the foreign currency would be: $P_{T}^{*}=\left(P_{1}^{*}\right)^{\beta}\left(P_{X}^{*}\right)^{1-\beta}$.

Assuming that foreign households as well as the foreign government consume the final good and the nontraded good the same way their domestic counterparts do, ${ }^{5}$ the foreign aggregate price level is given by:

$$
P^{*}=\left[\left(P_{N}^{*}\right)^{\gamma}\left(P_{T}^{*}\right)^{1-\gamma}\right]^{1-P u}\left[\left(P_{N}^{*}\right)^{g}\left(P_{T}^{*}\right)^{1-g}\right]^{P u}
$$

\section{Real exchange rate determination}

The exchange rate is defined as the foreign price of the domestic basket of consumption relative to the foreign price of a foreign basket of consumption. Combining (9) to (12) leads to the following expression:

$$
\frac{E P}{P^{*}}=\left(\frac{a_{x}}{a_{1}^{*}} \frac{a_{N}^{*}}{a_{N}} \frac{P_{X}^{*}}{P_{1}^{*}}\right)^{\gamma(1-P u)+g P u}
$$

\footnotetext{
${ }^{5}$ For the sake of simplicity, we assume that public spending as a share of total aggregate demand in the foreign country is the same as in the home country. Relaxing this assumption complicates the mathematics without generating additional interesting results.
} 


\section{ApPendix 2. Data}

Variable definition and source

\begin{tabular}{lll}
\hline Variable & Definition & Sources \\
\hline REER & CPI based Real effective exchange rate & Information Notice System, IMF \\
Oil & $\begin{array}{l}\text { Real oil price: UK Brent price deflated } \\
\text { by Manufacturing Unit value (MUV). }\end{array}$ & $\begin{array}{l}\text { World Economic Outlook (WEO), IMF, } \\
\text { DEC Database, World Bank. }\end{array}$ \\
DPROD & $\begin{array}{l}\text { Productivity differential: Real GDP per } \\
\text { employee relative to trading partners. }\end{array}$ & WEO, IMF \\
GK & $\begin{array}{l}\text { Government capital as share of GDP } \\
\text { REAL_M }\end{array}$ & WEO, IMF \\
& $\begin{array}{l}\text { Real Imports: Imports of Goods deflated } \\
\text { by the import unit value index. }\end{array}$ & WEO, IMF \\
& & \\
\hline
\end{tabular}

\section{Descriptive Statistics}

\begin{tabular}{lccccc}
\hline Variable & Mean & Median & Maximum & Minimum & Std. Dev. \\
\hline LREER & 5.146 & 5.449 & 5.871 & 4.392 & 0.511 \\
LOIL & 0.165 & 0.133 & 1.141 & -0.928 & 0.525 \\
LPROD & 0.352 & 0.345 & 0.761 & -0.079 & 0.292 \\
LGK & 3.403 & 3.371 & 3.630 & 3.246 & 0.104 \\
& & & & & \\
\hline
\end{tabular}

Note: LREER, LOIL, LPROD, LGK stand for the log of the real effective exchange rate, the log of the real price of oil, the $\log$ of the productivity differential between Algeria and the rest of the world, and the log of the ratio of capital expenditure to GDP, respectively. 
APPENDIX 3. ECONOMETRIC RESULTS

Granger Causality Tests (1969)

F-Statistic

\section{Capital Expenditure and Total Imports of Goods}

Ho: DLGK does not Granger Cause DLREAL_M

Notes: Since all variables are integrated of order one, I(1), we run the Granger-Causality test using their first differences. DLGK and DLREAL_M stand for the first log difference of the ratio of capital expenditure to GDP and the first log difference of real imports, respectively. The F-statistics displayed in the table are the Wald statistics for the joint assumptions: $\delta_{l}=0$ with $\mathrm{l}=1,2, \ldots, \mathrm{r}$, and $\delta_{s}=0$ with $\mathrm{s}=1,2 \ldots, \mathrm{u}$. ** denotes significance of the estimates at 5 percent critical level; * denotes significance of the estimates at 10 percent critical level. 